\title{
US muddles policy on fetal tissue
}

The failure of the US Congress to override the administration's veto of a bill to allow research with fetal tissue is a bad business, both for research and the civility of the coming election campaign.

THE United States, once the epitome of modernity, is coming to seem incorrigibly old-fashioned. The administration's decision that not a cent of federal money will go into fetal tissue research, and the failure last week of Congress to override President George Bush's veto of a bill that would have allowed it (see Nature 357, 267; 1992), bears out the assertion. The administration's familiar and well-advertised objection is that most of the fetal tissue now available derives from voluntary abortions, so that encouragement for fetal tissue research would imply that the federal government condones voluntary abortion. (The argument that proof of therapeutic techniques based on the use of fetal tissue would even encourage voluntary abortion, fecklessly innocent as it is of the reasons why 1.5 million women a year in the United States seek abortions, is not to be taken seriously.) This position is not even ideological, but is symbolic only.

There are two kinds of potential uses for fetal tissue in the treatment of postnatal disease. Because it is immunologically immature, it is likely to be more readily compatible than mature tissue when used as grafts. And neuronal fetal tissue, the cells of which divide rapidly in embryogenesis, but hardly at all in adult life, may have a special part to play in neurological diseases such as parkinsonism (but that point has not yet been proved). Nobody would claim, at least at this stage, that the promise of the therapies that may follow from research with fetal tissue is comparable with that of gene therapy, for example. But research may show that some congenital diseases of the blood-forming system, as well as parkinsonism and other like conditions, may be tractable by fetal grafts and not easily by other means.

Morally, of course, it is irrelevant that fetal tissue grafting is likely never to be simple or a dominant part of medical practice: the mythical housemaid was not excused the illegitimacy of her baby because it was only a small one. Bush's White House thus argues that it stands on a matter of principle: if research shows fetal tissue to be valuable in medicine, and if aborted tissue is then used as grafts, the administration will be held to have connived in proving that aborted tissue has medical uses and will thus have condoned abortion. It believes its case is strengthened by the likelihood that aborted tissue would be used in the research. But, even in the White House view, that argument can be turned around. Would not the supposed sin of abortion be mitigated - not absolutely, but to some degree - by the use of fetal tissue in therapy?

That argument is not nearly as unprincipled as many theologians hold. The United States boasts of its ability to accommodate diverse opinions. Now, there is a disturbing and sharp conflict on whether abortion should be legally permitted. (The Supreme Court's decision two weeks ago that states are free to act independently will make the conflict more audible by multiplying by lifty the number of campaigns for legislative change.) No wonder that abortion is likely to be prominent in the election campaign ahead.

But is it not the proper function of the government in a pluralistic society so to manage its affairs that substantial sections of opinion are not given a sense of being oppressed? That, indeed, is the line the White House has taken in its refusal to abridge the right of US citizens to buy guns (although Kalashnikovs and the like are now off bounds). Elsewhere, the abortion issue (nowhere settled) has been made manageable by subtlety blended with tolerance. To acknowledge that those who hold to the 'right to life' as well as to 'women's rights to self-determination' do so with great passion is not necessarily to allow that great passions make good policy. When some hold that voluntary abortion is deliberate murder, and others that it is a necessary instrument of social policy, serious conflict is unavoidable. People employ politicians to manage their affairs because they believe them to be skilled at the art of compromise. On this issue, the Bush administration has seemed more anxious to keep old friends than to win new ones.

Bush need not have dug in his heels on fetal tissue research. By doing so, he has given a hostage to fortune and an illustration of the administration's willingness to interfere with the administration of research. (The device of specifying what granting agencies may and may not do with federal funds is becoming uncomfortably familiar.) But Bush may also have delayed therapy for many who need it.

\section{Protest by barricade}

Road-blocks are in the best French traditions, but this time deepen the shadow over the European enterprise.

THE book Clochemerle, later a successful film, which demonstrated the depths of Gallic passion even over small issues, is one recollection evoked by the barricades thrown over major highways last week by French truck drivers protesting at new strict regulations of drivers' licences. Another is the long period of student protest which, in 1968, made parts of Paris impassable - and which (among other 